RESEARCH PAPER

\title{
Anti-Nutritional Factors in Food and Plant Crops
}

\author{
V.K. Joshi ${ }^{1 *}$, Ghan Shyam Abrol ${ }^{2}$ and Amit Kumar Singh ${ }^{1}$ \\ ${ }^{1}$ Department of Food Science and Technology, Dr Y S Parmar Universisty of Horticulture and Forestry Nauni, Solan, India \\ ${ }^{2}$ Department of Post-harvest Technology, Rani Lakshmi Bai Central Agricultural University, Jhansi, India
}

*Corresponding author: vkjoshipht@rediffmail.com

Paper No.: 248

Received: 15-09-2020

Revised: 22-11-2020

Accepted: $14-12-2020$

\begin{abstract}
Some of plants mainly contains toxic compound such as saponins, tannins, phytic acid, gossypol, lectins, protease inhibitors, amylase inhibitor, goitrogens etc. which limits their consumption and also reduces nutrient bioavailability when consumed. These factors are responsible for micronutrient malnutrition and mineral deficiencies. On the other hand they act as self defense system to the food. These are categorized into different categories and causes various symptoms upon consumption such as acute toxicity include respiratory distress, impaired body weight gain, anorexia, weakness, apathy and in some cases even death after several days. But there are various traditional methods and improved technologies are available, which can be used to reduce the levels of these anti-nutrient factors. Various processing methodologies such as fermentation, germination, debranning, autoclaving, soaking, drying, irradiation etc. are used to reduce the anti-nutrient contents in foods. The review is focused on some common recently important anti-nutritional factors (ANF) which were of major concern.
\end{abstract}

Keywords: Anti-nutrients, Saponins, Trypsin Inhibitors, Cooking, Fermentation, Irradiation

The anti-nutritional factors (ANF) are the toxic compounds synthesized naturally in plant, microbes and animals cause serious problems in human and animal nutrition. These are compounds which reduces the nutrient utilization or food intake when consumed as foods (Soetan and Oyewole, 2009). The presence of these endogenous compounds results in limiting use of food or feed stuff.

The ANFs can be divided into two major categories. One category is of proteins (such as lectins and protease inhibitors) which are sensitive to normal processing temperatures and second is of other substances which are stable or resistant to these temperatures and include among many others polyphenolic compounds (mainly condensed tannins), non-protein amino acids and galactomannan gums. According to Aletor (1993) there are several ANFs that are very significant in plants used for human foods and animal feeds (Fig. 1). They are enzyme inhibitors (trypsin and chymotrypsin inhibitors, plasmin inhibitors, elastase inhibitors), haemaglutinnins (concanavalin A, ricin), plant enzymes (urease, lipoxygenase), cyanogenic glycosides (phaseolunatin, dhurrin, linamarin, lutaustralin), goitrogens (pro-goitrins, glucosinolates), oestrogens (flavones, genistein), saponins (soya sapogenin), gossypol from Gossypium species e.g., cotton, tannins (condensed and hydrolysable tannins), amino acid analogues (BOAA, DAP, mimosine, N-methyl-1- alanine), alkaloids (solanine, chaconine), anti-metals (phytates, oxalates), anti-vitamins (anti-vitamins A, D, E and B12) and favism factors.

How to cite this article: Joshi, V.K., Abrol, G.S. and Singh, A.K. (2020) Anti-Nutritional Factors in Food and Plant Crops. Int. J. Food Ferment. Technol., 10(2): 101-111.

Source of Support: None; Conflict of Interest: None 


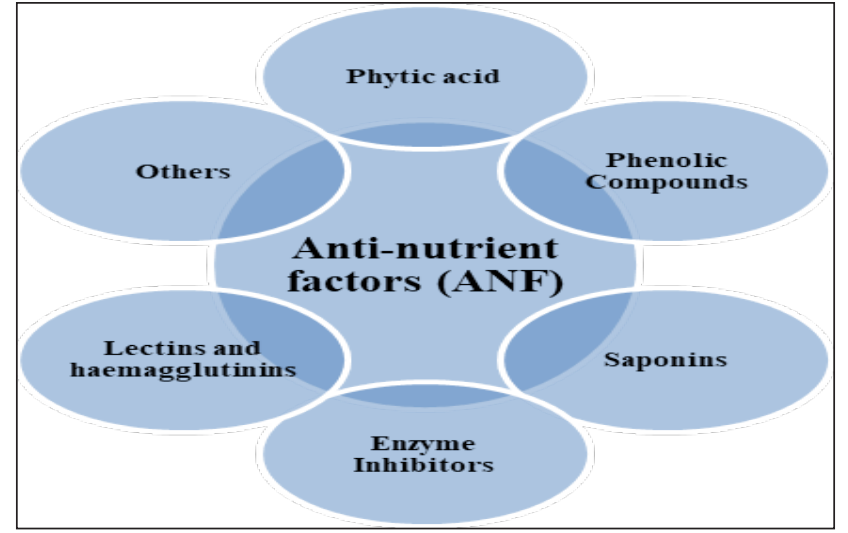

Fig. 1: Classification of anti-nutrients present in food (Samtiya et al. 2020)

Although these factors vary in their individual effect, a large proportion of them can be destroyed or inactivated simply by heat treatment processes during cooking. Unfortunately, detailed toxicological studies have not been performed on the majority of these anti-nutritional factors. Broadly speaking, their presence in untreated foodstuffs normally results in anorexia, reduced growth and poor food conversion efficiency when used at high dietary concentrations. Most of legumes are under-used because of the presence of anti-nutritional compounds, such as enzyme (trypsin, chymotrypsin, alpha-amylase) inhibitors, phytic acid, flatulence factors, saponins and toxic factors (Lyimo et al. 1992). Root crops, in common with most plants, contain small amounts of potential toxins and antinutritional factors such as trypsin inhibitors. Apart from cassava that has cyanogenic glucosides, cultivated varieties of most edible tubers and roots do not contain any serious toxins. Thus, wild species must be properly processed before their consumption. These wild species, however, are useful reserves in times of famine or food scarcity. Local people are aware of their potential risks in their use and have developed indigenous techniques to detoxify such crops before consumption.

\section{SAPONINS}

Saponins are glycosides present in plants and due to hydrophobic nature of aglycone and hydrophilic nature of sugar chains results in distinctive foaming characteristic (Price et al. 1987). The word is derived from Latin word sapo from soapwort plant (Saponaria). They are either a choline steroid or triterpenoid attached via C3 and an ether bond to a sugar side chain. Most of the saponins occur as insoluble complexes with 3-b-hydroxysteroids which interact with bile acid and cholesterol, similarly, saponin with either of iron, zinc, and calcium form insoluble complexes (Oakenfull et al. 1989; Milgate and Roberts, 1995; Rafińska et al. 2017). Soybean, chickpea, faba bean, pea, lentil and peanuts are the different sources of saponins. Erythrocytes lyse in saponin solution, therefore these compounds are toxic when injected intravenously (Khalil and ElAdawy, 1994). Saponin content may be variable, even among the same species of edible beans, because of variations in cultivars, varieties, locations, irrigation condition, type of soil, climatic conditions, and year during which they are grown (Price et al. 1987; Khokhar \& Chauhan, 1986; Fenwick \& Oakenfull, 1983; Gholami et al. 2014; Bianca et al. 2020). High concentrations impart a bitter taste and astringency in dietary plants causes its limited use as food (Liener, 1994). The anti-nutritional effects of saponins have been mainly studied using alfalfa saponins. Saponins cause hypocholesterolaemia by binding cholesterol, making it unavailable for absorption. They also cause haemolysis of red blood cells and are toxic to rats (Johnson et al. 1986). Saponins have wide applications in beverages, confectionery and pharmaceutical products (Sparg et al. 2004; Petit et al. 1995; Uematsu et al. 2000).

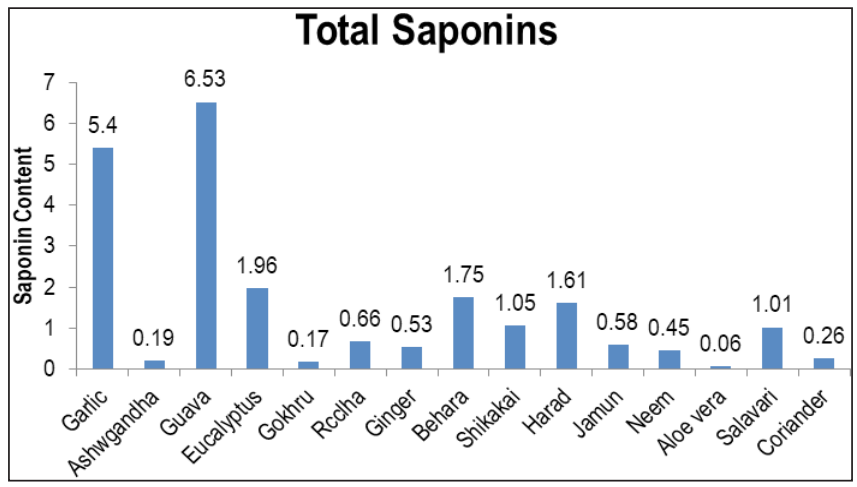

Fig. 2: Presence of total saponins content in commonly used spices (Sirohi et al. 2009) 
Soaking, blanching, cooking and other treatments reduce the saponins content. Cooking of legumes reduces the amount of saponins by $7-53 \%$ (Jood et al. 1986; Sharma and Sehgal, 1992). Cooking of chickpea and black gram and of faba beans lowered the saponin content by $7-17 \%$ and $35 \%$, respectively (Kataria et al. 1988).

\section{TRYPSIN INHIBITOR}

Legumes are low cost source of protein in the diet (Borade et al., 1984). But another side they also contains some anti-nutritional factors like trypsin which is injurious to human health (Soetan and Oyewole, 2009). Trypsin inhibitior strappingly prevent the activity of key pancreatic enzymes trypsin and chymotrypsin thus reducing digestion and absorption of proteins by the formation of different complexes (Gemede and Ratta, 2014). These are classified in 2 families as per their molecular size: Kunitz (KTIs), having molecular weights around 20 kDa and Bowman-Birk (BBTIs) around 8 kDa (AvilésGaxiola et al. 2018). The tripsin inhibitor content of legumes increased during germination. The intake of trypsin inhibitor with the diet causes a rise of fecal nitrogen loss (Combs et al. 1967).

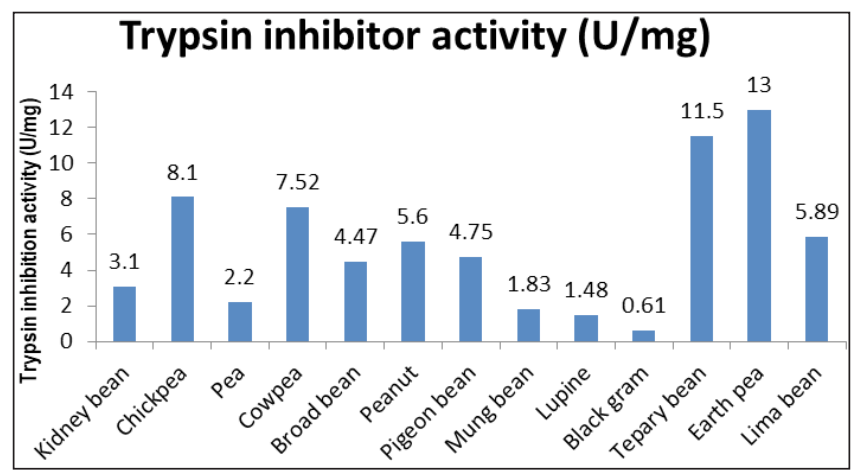

*Trypsin inhibition activity of Soyabean is $94.1 \mathrm{U} / \mathrm{mg}$ (Yalcin and Basman, 2015)

Fig. 3: Trypsin inhibitor activity in different legumes (Avilés-Gaxiola et al. 2018)

Trypsin inhibitor may have different modes of action, such as the antifibrinolytic or antithrombinogenic or antiproteolytic or a promoter of conversion of methionine to cysteine manifesting ultimately in growth retardation. Trypsin (protese inhibitor) causes pancreatic enlargement and growth depression (Aletor and Fetuga, 1987). Cooking and germination seem to be good procedures to improve the quality of lentil flour from the nutritional point of view, despite the fact that a large variation on the effects of processing, related to the different legume varieties, has been observed (Vidal et al. 1994).

Table 1: Different treatments to reduce the Trypsin inhibitor

\begin{tabular}{|c|c|c|}
\hline Treatments & Effect & References \\
\hline \multirow[t]{4}{*}{$\begin{array}{l}\text { Thermal } \\
\text { treatments }\end{array}$} & $\begin{array}{l}\text { Pressure cooking reduces } \\
\text { trypsin inhibitors by 50\% } \\
\text { while microwaving } 25 \%\end{array}$ & Habiba, 2002 \\
\hline & $\begin{array}{l}\text { Chickpeas needed } \\
\text { minimum } 90 \text { minutes of } \\
\text { boiling or } 35 \text { minutes of } \\
\text { autoclaving or } 15 \text { minutes } \\
\text { of microwaving }\end{array}$ & $\begin{array}{l}\text { Alajaji and El- } \\
\text { Adawy, } 2006\end{array}$ \\
\hline & $\begin{array}{l}\text { Lentils, require only } 1 \\
\text { min roasting at } 80^{\circ} \mathrm{C} \text { to } \\
\text { reduce up to } 95.6 \% \text { trypsin } \\
\text { inhibitors and also total } \\
\text { tannins and phytic acid. }\end{array}$ & $\begin{array}{l}\text { Embaby, 2010a; } \\
\text { Ma and other } \\
2011\end{array}$ \\
\hline & $\begin{array}{l}4 \mathrm{~h} \text { soaking followed by } \\
\text { cooking at } 95^{\circ} \mathrm{C} \text { for } 1 \mathrm{~h} \text { the } \\
\text { trypsin inhibition of pea, } \\
\text { lentil, faba bean, chickpea, } \\
\text { and common bean } \\
\text { reduced } 81.25 \%, 100 \% \text {, } \\
100 \%, 88.37 \% \text {, and } 93.7 \% \text {, } \\
\text { respectively }\end{array}$ & $\begin{array}{l}\text { Pedrosa and } \\
\text { others 2015; Shi } \\
\text { and others } 2017\end{array}$ \\
\hline \multirow[t]{2}{*}{ Extrusion } & $\begin{array}{l}\text { Extrusion cooking after } \\
\text { pre-treatment at different } \\
\text { high temperatures to } \\
\text { the legumes field pea, } \\
\text { chickpea and faba bean } \\
\text { flour resulted in reductions } \\
\text { of up to } 53.7 \%, 91.8 \% \text {, and } \\
58.9 \% \text {, respectively }\end{array}$ & $\begin{array}{l}\text { Adamidou and } \\
\text { others } 2011\end{array}$ \\
\hline & $\begin{array}{l}\text { Soybeans and lentil, } \\
\text { extrusion at } 150{ }^{\circ} \mathrm{C} \text { found } \\
\text { to be enough to inactivate } \\
\text { trypsin inhibitors activity } \\
\text { up to } 95 \%\end{array}$ & $\begin{array}{l}\text { Žilić and others } \\
\text { 2012; Rathod and } \\
\text { Annapure } 2016\end{array}$ \\
\hline
\end{tabular}


P Joshi et al.

\begin{tabular}{|c|c|c|}
\hline Ultrasound & $\begin{array}{l}\text { Ultrasound waves } 30 \mathrm{kHz} \\
\text { for } 20 \text { min in soybeans } \\
\text { decreases } 55 \% \text { of Kunitz } \\
\text { Trypsin inhibitor }\end{array}$ & $\begin{array}{l}\text { Huang and } \\
\text { others } 2008\end{array}$ \\
\hline $\begin{array}{l}\text { High } \\
\text { hydrostatic } \\
\text { pressure }\end{array}$ & $\begin{array}{l}\text { Protein digestibility was } \\
\text { improved by } 4.3 \% \text { and } \\
8.7 \% \text { in split peas and } \\
\text { white beans }\end{array}$ & $\begin{array}{l}\text { Linsberger- } \\
\text { Martin and } \\
\text { others } 2013\end{array}$ \\
\hline $\begin{array}{l}\text { Infrared } \\
\text { radiation (IR) }\end{array}$ & $\begin{array}{l}\text { IR exposure completely } \\
\text { inactivates trypsin } \\
\text { inhibitor and lipoxygenase } \\
\text { enzymes in soybean }\end{array}$ & Bellido et al. 2006 \\
\hline Soaking & $\begin{array}{l}\text { Simplest way of } \\
\text { inactivation of trypsin } \\
\text { inhibitor activities }\end{array}$ & $\begin{array}{l}\text { El-Adawy et al. } \\
\text { 2000; Mumba et } \\
\text { al. } 2004\end{array}$ \\
\hline Germination & $\begin{array}{l}\text { Germination reduces } \\
\text { trypsin inhibitor }\end{array}$ & $\begin{array}{l}\text { Sangronis and } \\
\text { Machado } 2007\end{array}$ \\
\hline Fermentation & $\begin{array}{l}\text { Solid-State Fermentation in } \\
\text { A. oryzae over a period of } 5 \\
\text { days reduces } 89.2 \% \text { trypsin } \\
\text { activity }\end{array}$ & Gao et al. 2013 \\
\hline
\end{tabular}

\section{MIMOSINE}

Mimosine [B-N-(3-hydroxy-4-pyridone)-a-aminopropionic acid], a non-protein amino acid structurally resembles to tyrosine and found in the genera Leucaena and Mimosa. The mimosine contents in different parts varies differently as in seeds 4 to $5 \%$, in roots 1 to $1.5 \%$ and in shoot 1 to $12 \%$ similarly old stems have the smallest and growing tips contains largest amounts (Jones and Lowry, 1984). The mechanism of action of mimosine in producing its effect, however, is not clear but it may act as an amino acid antagonist or may complex with pyridoxal phosphate, leading to disruption of catalytical action of $\mathrm{B}_{6}$-containing enzymes such as trans-aminases, or may complex with metals such as zinc (Hegarty, 1978). The main symptoms of toxicity in ruminants are poor growth, loss of hair and wool, swollen and raw coronets above the hooves, lameness, goitre etc. (Jones and Hegarty, 1984). Moist heat at 70 to $100^{\circ} \mathrm{C}$ reduce $50 \%$ mimosine content (Akbar and Gupta, 1985) and dry heat treatment at $100^{\circ} \mathrm{C}$ reduced 17 to $19 \%$ mimosine content whereas autoclaving reduced 19 to 23\% (Mali et al. 1990).

\section{CYANOGENS (CNglcs)}

Cyanogenic glucosides are phytoanticipins of more than 60 different types and known to be present in more than 2500 plant species (Conn, 1980; Bak et al. 2006). Generally, CNglcs acts as defense mechanism to plants which resulted in release of toxic hydrogen cyanide (HCN), an aldehyde or ketone and glucose compounds (Nahrstedt, 1996; Vetter, 2000). The lethal dose of cyanide for vertebrates lies in the range of $35-150 \mu \mathrm{mol} / \mathrm{kg}$ (Zagrobelny et al. 2008). Generally, cyanogenic glycoside is considered as not toxic on its own (Bolarinwa et al. 2016).

A cyanogenic food of particular economic importance is cassava, which is also known by the names manioc, yuca and tapioca. Cassava roots have been reported to contain cyanide content of $10-500 \mathrm{mg} / \mathrm{kg}$ of dry matter (Siritunga and Sayre, 2003). Amygdalin is the cyanogenic glycoside responsible for the toxicity found in the range of $8.84-48.33 \mathrm{mg} / \mathrm{g}$ in Cassava (Bolarinwa et al. 2016) and also in many species of Rosaceae, such as bitter almonds, peaches and apricots (Bolarinwa et al.2014). Sweet almonds are low in amygdalin as a result of breeding processes. The lethal dose of HCN for cattle and sheep is $2.0-4.0 \mathrm{mg}$ per kg body weight. The lethal dose for cyanogens would be $10-20$ times greater because the HCN comprises $5-10 \%$ of their molecular weight (Conn, 1979). Cyanide content of bamboo shoot ranged from 1000 to $8000 \mathrm{mg} / \mathrm{kg}$ hydrogen cyanide (Ferreira et al. 1995). For poisoning, forage containing this amount of cyanogens would have to be consumed within a few minutes and simultaneous HCN production would have to be rapid. Recorded accounts of livestock poisoning by cyanogenic plants show that such situations do arise. Cyanogens have also been suspected to have teratogenic effects (Keeler, 1984). Post-harvest wilting of cyanogenic leaves may reduce the risk of cyanide toxicity. Animals suffering from cyanide must be immediately treated by injecting a suitable dose of sodium nitrate and sodium thiosulphate. 
Table 2: Different treatments to reduce the cyanogens

\begin{tabular}{|c|c|c|}
\hline Treatments & Effect & References \\
\hline \multirow[t]{2}{*}{ Soaking } & $\begin{array}{l}\text { Soaking of cassava root } \\
\text { for } 72 \mathrm{~h} \text { reduces } 90 \% \text { of } \\
\text { cyanide content }\end{array}$ & $\begin{array}{l}\text { Kemdirimi et al. } \\
1995\end{array}$ \\
\hline & $\begin{array}{l}\text { Soaking of apricot } \\
\text { kernels at } 20^{\circ} \mathrm{C} \\
\text { significantly reduces } \\
\text { amygdalin }\end{array}$ & Tuncel et al. 1995 \\
\hline \multirow[t]{3}{*}{ Fermentation } & $\begin{array}{l}\text { Fermentation of cassava } \\
\text { pulp or dough for } 4-5 \\
\text { days has been reported } \\
\text { to decrease its total } \\
\text { cyanide by } 52-63 \%\end{array}$ & $\begin{array}{l}\text { Kemdirimi et al., } \\
1995\end{array}$ \\
\hline & $\begin{array}{l}\text { Fermentation of } \\
\text { cocoyam flour reduces } \\
\text { cyanide by } 98.6 \%\end{array}$ & Igbadul et al. 2014 \\
\hline & $\begin{array}{l}\text { Fermentation results in } \\
\text { reduction of } 84.6 \% \text { in } \\
\text { the cyanide content in } \\
\text { sorghum leaves }\end{array}$ & $\begin{array}{l}\text { Prasad and Dhanya, } \\
2011\end{array}$ \\
\hline Storage & $\begin{array}{l}\text { Cyanide content } \\
\text { decrease by } 50-64 \% \\
\text { in the cassava product } \\
\text { when stored for } 4 \text { weeks } \\
\text { at room temperature }\end{array}$ & Onabolu et al. 2002 \\
\hline
\end{tabular}

\section{OXALATES}

Oxalates were found in various families including aroid / arum family e.g., Colocasia (taro) and Xanthosoma (Calodium) (Noonan and savage, 1999). Oxalic acid result of oxidative breakdown of carbohydrate and protein, accumulated in plants especially during dry conditions (Bressani et al. 1993). Reports of some tropical leafy vegetables revealed that dry vegetables had higher oxalate concentrations than the fresh vegetables (Aletor and Adeogun, 1995). Oxalate content in taro (Colocasia esculenta) contain 278-574 mg /100 g fresh weight, sweet potato (Ipomoea batatas) $470 \mathrm{mg} / 100 \mathrm{~g}$ fresh weight and yam (Dioscorea alata) tubers $486-781 \mathrm{mg} / 100 \mathrm{~g}$ dry were reported (Holloway et al. 1989; Mosha et al. 1995). Oxalate was widely distributed in plants in a readily water soluble form as potassium, sodium and ammonium oxalate and as insoluble calcium oxalates (Fassett, 1973; Connor, 1977; Smith, 1982).
The content of total oxalate, soluble oxalate, calcium oxalate and free calcium for various aroids as summarized in Table 3. Holloway et al. (1989) found that the stems of giant swamp taro, elephant foot yam, skin of giant taro and taro leaves contained about $400 \mathrm{mg} / 100 \mathrm{~g}$ fresh weight of calcium oxalate, about 10 times the amount present in taro Xanthosoma and Colocasia.

Table 3: Content of calcium oxalates and calcium $(\mathrm{mg} / 100 \mathrm{~g}$ fresh weight) in roots and stems of tropical root crops (standard deviation in parentheses)

\begin{tabular}{|c|c|c|c|c|}
\hline Root crop and source & $\begin{array}{c}\text { Total } \\
\text { oxalate }\end{array}$ & $\begin{array}{l}\text { Soluble } \\
\text { Oxalate }\end{array}$ & $\begin{array}{l}\text { Calcium } \\
\text { Oxalate }\end{array}$ & $\begin{array}{c}\text { Total } \\
\text { Ca }\end{array}$ \\
\hline \multicolumn{5}{|l|}{ 1. taro, Colocasia esculenta } \\
\hline $\begin{array}{l}\text { (a) Fiji croms, mean of } 5 \\
\text { Cvs. }\end{array}$ & $65(19)$ & $35(4)$ & 43 & $23(5)$ \\
\hline $\begin{array}{l}\text { (b) Fiji, suckers, mean of } 2 \\
\text { Cvs. }\end{array}$ & $60(1)$ & - & - & $14(2)$ \\
\hline $\begin{array}{l}\text { 2. taro, X. sagittifolium } \\
\text { tonga corms, mean of } 3 \\
\text { Cvs. }\end{array}$ & $60(30)$ & $44(22)$ & 23 & $6(1)$ \\
\hline \multicolumn{5}{|l|}{ 3. giant taro, Alocasia } \\
\hline $\begin{array}{l}\text { (a) Western Samoa, mean } \\
\text { of } 6 \text { Cvs. }\end{array}$ & $38(18)$ & $17(9)$ & 31 & $26(5)$ \\
\hline $\begin{array}{l}\text { (b) Western Samoa mean of } \\
6 \text { Cvs. }\end{array}$ & $30(8)$ & - & - & $28(9)$ \\
\hline \multicolumn{5}{|l|}{$\begin{array}{l}\text { 4. giant swamp taro, } \\
\text { Crytosperma }\end{array}$} \\
\hline $\begin{array}{l}\text { (a) Fed. States of } \\
\text { Microneisa (Ponape), Mean } \\
\text { of } 2 \text { Cvs. }\end{array}$ & $\begin{array}{l}319 \\
(77)\end{array}$ & $45(39)$ & 399 & $\begin{array}{l}135 \\
(33)\end{array}$ \\
\hline (b) Kiribati, mean of 5 Cvs. & $\begin{array}{c}300 \\
(218)\end{array}$ & - & - & $\begin{array}{c}219 \\
(156)\end{array}$ \\
\hline
\end{tabular}

Source: Holloway et al. (1989).

Raw, unpeeled Colocasia (Colocasia esculenta) corm meal contained total oxalate $1234 \mathrm{mg} / \mathrm{kg}$ of dry matter. About a third of the oxalates were removed during peeling the outer skin of the corms, and when peeling was combined with boiling, oxalate contents were reduced to $272 \mathrm{mg} / \mathrm{kg}$. The data suggested that oxalate was a major factor contributing to the antipalatability and antinutritive effect of raw Colocasia corm. Shajeela et al. (2011) observed that D. bulbifera var. vera content highest amount of total 
free phenolics $(2.20 \mathrm{~g} / 100 \mathrm{~g}$ on dry wt. basis) and total oxalate $(0.78 \mathrm{~g} / 100 \mathrm{~g}$ on dry wt. basis) in all species of yam. Bhandari and Kawabata (2004) studied on oxalate content in four species of yam and found that the $D$. deltoidea content highest amount of total oxalate, soluble oxalate and calcium oxalate followed by $D$. triphylla, D. versicolor and D. Bulbifera.

Singh et al., (1999) studied on biochemical composition and nutririve value of promising collections of elephant foot yam of five genotype like Am-1, Am-2, Am-3, Am-4, Am-5, and found that Am-5 contained highest amount of oxalate $(0.96 \%)$ and Am-1 $(0.58 \%)$ was the lowest. Chattopadhyay et al. (2010) studied on quantitative and qualitative aspects of elephant foot yam corm and found that the genotype NDA4 contained highest amount of soluble oxalate (18.50 $\mathrm{mg} / 100 \mathrm{~g}$ ) while, Midnapur Finger was lowest in amount (6.65 mg/100g). Oscarsson and Savage (2007) studied on composition and availability of soluble and insoluble oxalates in raw and cooked taro (Colocasia esculenta var. Schott) leaves and found that young taro leaves contained $589 \mathrm{mg}$ total oxalate/100g fresh wt. while older taro leaves contained $443 \mathrm{mg}$ total oxalate $/ 100 \mathrm{~g}$ fresh wt. and soluble oxates were $74 \%$ of total oxalate content of the young and old leaves. They also studied on soluble and insoluble oxalate in young and old leaves with treatment of fresh, baked and baked with milk and found that the old leaves contained highest per cent of soluble and lowest per cent of insoluble oxalate, while, old leaves baked with milk contained lowest soluble and highest insoluble per cent of oxalate. Frank et al., (2001) studied on oxalate, insoluble calcium and soluble oxalate in Phaseolus vulgaris leaves and found that the adult leaf contained more amount of oxalte than the growing leaf on dry weight basis.

Hang et al. (2012) studied on effect of simple washing processing methods on oxalate content of taro petioles and found that petioles and leaves of cv. Chia Voi contained lowest soluble and total oxalate in washed sample, and highest in raw sample. Cooking at 45 minute at 15 psi pressure reduced the total, soluble and insoluble content of all vegetables (silverbeet leaf, silverbeet stem, New Zeland spinach,
Spinach, Rhubarb stalk, Beetroot, Broccoli, Carrot, Parsnip) Savage et al. (2000). Freezing followed by grilling reduces the availability of calcium as $76.7 \%$ of calcium was bound to oxalate to insoluble oxalate form (Brogren and Savage, 2003). Similarly, the oxalate content of spinach pasta was found to contained highest amount of total $(91.8 \mathrm{mg} / 100 \mathrm{~g}$ wet weight) and soluble oxalate $(53.8 \mathrm{mg} / 100 \mathrm{~g}$ wet weight (Liebman and Okombo, 2009).

\section{GLYCOALKALOIDS}

Potatoes are good source of glycol-alkaloids alphasolanine and alpha-chaconine, concentrated mainly in the flowers and sprouts (200 to $500 \mathrm{mg} / 100$ g). For food safety purposes, an upper limit for glycoalkaloid content of $20 \mathrm{mg}$ per $100 \mathrm{~g}$ of potato is generally accepted. Concentrations of glycoalkaloids are 3 to 10 times greater in the peel than in the flesh. In bitter varieties, the alkaloid concentration can go upto $80 \mathrm{mg} / 100 \mathrm{~g}$ in the tuber as a whole and up to $150-220 \mathrm{mg} / 100 \mathrm{~g}$ in the peel. At these concentrations of solanine and other potato glycoalkaloids are toxic. But because of higher temperature of decomposing $\left(243{ }^{\circ} \mathrm{C}\right)$ they remain unaffected at normal cooking. To avoid toxic levels of glycoalkaloids, potato cultivar selection is very important. However, improper postharvest handling conditions are the main cause of toxic levels in potatoes. To keep glycoalkaloid content low, store potatoes at lower temperatures, such as $7^{\circ} \mathrm{C}$, keep potatoes away from light, market in opaque plastics films and paper bags, and rotate frequently on retail displays.

\section{LECTINS}

Lectins are proteins or glycoproteins with molecular weight of 10, 000-124, 000. Lectins, also referred to as phyto-haemagglutinins, are glycoprotein compounds which have been shown to agglutinate red blood cells in vitro (Gatel, 1994). It is also defined as 'proteins or glycoproteins of non-immune origin with one or more binding sites per subunit, which can reversibly bind to specific sugar segments through hydrogen bonds and Van Der Waals interactions' (Lis and Sharon, 1998). Lectin activity has been determined in 
more than 800 varieties of the legume family. Of the total protein 2- 10 per cent legume seeds are lectins. One of their most important characteristics is that they prevent absorption of digestive end products in the small intestine. In general, plant lectins are most abundant in the seeds but they are also found in different vegetative tissues such as in roots, leaves, barks, flowers, bulbs and rhizomes (Ratanapo et al. 1998; Van Damme et al. 2000). Soybean, common bean, jack bean, chickpea, faba bean, pea, lentil and peanut are good sources of lectins. Peas generally have higher lectin activities than faba beans, but both show considerably lower amounts in comparison to raw defatted soybeans. Effects of feeding lectin containing diets include changes in gut immune function, reduced production of endocrine cells and gut hormones, interference with the bacterial ecology in the gut lumen, and damage to mucosal cells (King et al., 1983). Lectins have the capability to directly bind to the intestinal mucosa interacting with the enterocytes and interfering with absorption and transportation of nutrients (particularly carbohydrates) during digestion and causing epithelial lesions within the intestine (Santiago et al. 1993, Oliveira et al. 1989). The main toxic components in P. vulgaris are lectins, sugar-binding proteins which bind and agglutinate red blood cells. The toxicity of lectins is characterized by growth inhibition in experimental animals and diarrhoea, nausea, bloating and vomiting in humans. But thorough cooking can destroy this to a safe limit. Armour et al. (1998) reported a complete inactivation of soy lectin and protease inhibitory activity by aqueous heat treatment of fully imbibed soy seeds at $100^{\circ} \mathrm{C}$ for $10 \mathrm{~min}$.

\section{GOSSYPOL}

Gossypol is a phenolic compound first isolated in 1899 and its name is derived from the genus scientific name (Gossypium) combined with the "ol" from phenol (Soto-Blanco, 2008). Gossypol is produced by pigment glands in cotton stems, leaves, seeds, and flower buds but the highest concentration is seen in seeds (Rogers et al. 2002; Kenar, 2006; Alexander et al. 2008). General signs of acute toxicity include respiratory distress, impaired body weight gain, anorexia, weakness, apathy and in some cases even death after several days (Fombad and Bryant, 2004). The amount of free gossypol in the cottonseed can be quite variable. Many factors influence gossypol content such as: specie of cotton plant, climatic conditions, soil conditions, fertilizer, etc. Since gossypol affects the heart, gossypol toxicity has been manifested as two types of clinical syndromes particularly in young animals. Dietary gossypol can also bring about increased requirement, not only for lysine, but also for iron which it can chelate. At the physiological level, gossypol reduces oxygen availability in the blood. One syndrome of sudden death (resembling a heart attack) has frequently been reported in calves and lambs. Dietary free gossypol of up to $0.02-0.03 \%$ has been reported to cause death in growing pigs while poultry can tolerate fairly high dietary levels (Aletor and Onibi, 1990). These animals seem healthy, have good appetites and are

Table 4: Treatments to Reduce Gossypol Toxicity

\begin{tabular}{|c|c|c|}
\hline Treatments & Effect & References \\
\hline Heat treatment & $\begin{array}{l}\text { Roasting \& Extrusion both reduces the } \\
\text { gossypol content in milk }\end{array}$ & Arieli,1998; Noftsger et al. 2000 \\
\hline Irradiation & $\begin{array}{l}\text { Gamma irradiation \& Electron beam } \\
\text { irradiation reduces gossypol content in } \\
\text { cottonseed meal }\end{array}$ & $\begin{array}{l}\text { Quintana et al. 2000; Sijun et al. 2012; Shawrang et al. 2011; } \\
\text { Ebrahimi-Mahmoudabad and Taghinejad-Roudbaneh, } \\
2011\end{array}$ \\
\hline Fermentation & $\begin{array}{l}\text { Fungus Aspergillus niger, Aspergillus oryzae, } \\
\text { Candida tropicalis, Saccharomyces cerevisiae, } \\
\text { Geotrichum candidum found to be very effective } \\
\text { in reducing Gossypol Toxicity }\end{array}$ & Barros et al. 2002; Yildirim et al. 2003; Lim and Lee, 2011 \\
\hline
\end{tabular}


often one of the best ones in the group, but are found dead. If cotton seed or cotton seed meal is bought in bulk, it would be worthwhile to have it tested before feeding it. Depending on the level of free gossypol, the cottonseed could be utilized in the best interest of the livestock.

\section{SUMMARY}

Antinutritional factors like saponin, trypsin inhibitors etc. are the defense mechanism of plants, yet these cause many ill effects when consumed. Antinutritional factor is a serious problem in wild species while most of cultivated species are devoid of it. Beside these, many processing practices are developed in these days to avoid the ill effect of antinutritional factors. Since, the antinutrional factors are defense mechanism of plants so these need to be exploited for the benefits of human use.

\section{REFERENCES}

Akbar, M.A. and Gupta P.C. 1985. Subabul (Leucaena leucocephala) as a source of protein supplement for buffalo calves. Indian Journal of Animal Sciences, 55: 54-58.

Aletor, V.A. 1993. Allelochemicals in plant foods and feeding stuffs. Part I. Nutritional, biochemical and physiopathological aspects in animal production. Veterinary and Human Toxicology, 35(1): 57-67.

Aletor, V.A. and Fetuga, B.L. 1987. Pancreatic and intestinal amylase (EC 3.2.1.1) in the rat fed haemagglutinin extract. II Evidence of impaired dietary starch utilization. J. Anim. Physiol. Anim. Nutr., 57(3): 113-117.

Aletor, V.A. and Onibi, O.E. 1990. The use of oyster shell as calcium supplement. Part I. Effect on the utilization of gossypol-containing cottonseed cake by the chicken. Die. Nahrung. Food, 34(4): 311-319.

Aletor, V.A. and Adeogun, O.A. 1995. Nutrient and antinutrient component of some tropical leafy vegetables. Food Chem., 53: 375-379.

Alexander, J., Benford, D., Cockburn, A. et al. 2008. Gossypol as undesirable substance in animal feed. EFSA Journal, 908: $1-55$.

Arab, A.A.A. and Salem, F.M.A. 2010. Nutritional quality of Jatropha curcas seeds and effect of some physical and chemical treatments on their anti-nutritional factors. African Journal of Food Science, 4(3): 93-103.

Arieli, A. 1998. Whole cottonseed in dairy cattle feeding: a review. Animal Feed Science and Technology, 72(1-2): 97-110.
Armour, J.C., Perera, R.L.C., Buchan, W.C. and Grant, G. 1998. Protease inhibitors and lectins in soya beans and effects of aqueous heat-treatment. J. Sci. Food Agric., 78: 225-231.

Avilés-Gaxiola, S., Chuck-Hernández, C. and Serna Saldívar, S.O. (2018), Inactivation Methods of Trypsin Inhibitor in Legumes: A Review. Journal of Food Science, 83: 17-29.

Bak, S., Paquette, S.M., Morant, M., Rasmussen, A.V., Saito, S., Bjarnholt, N., Zagrobelny, M., Jørgensen, K., Hamann, T., Osmani, S., Simonsen, H.T., Pérez, R.S., van Hesswijck, T.B., Jørgensen, B. and Møller, B.L., 2006. Cyanogenic glycosides; a case study for evolution and application of cytochromes P450. Phytochem. Rev., 5: 309-329

Barros, M.M., Lim, C. and Klesius, P.H. 2002. Effect of soybean meal replacement by cottonseed meal and iron supplementation on growth, immune response and resistance of channel catfish (Ictalurus puctatus) to Edwardsiella ictaluri challenge. Aquaculture, 207(3-4): 263279.

Bhandari, M.R. and Kawabata, J. 2004. Assessment of antinutritional factor and bioavailability of calcium and zinc in wild yam (D. spp) tubers of Nepal. Food Chemistry, 85: 281-287.

Bianca Ribeiro, Elia Lacchini, Keylla U. Bicalho, Jan Mertens, Philipp Arendt, Robin Vanden Bossche, Gabriela Calegario, Lore Gryffroy, Evi Ceulemans, Julia Buitink, Alain Goossens and Jacob Pollier. 2020. A Seed-Specific Regulator of Triterpene Saponin Biosynthesis in Medicago truncatula. The Plant Cell, 32(6): 2020-2042.

Bolarinwa, I.F., Oke, M.O., Olaniyan, S.A. and Ajala, A.S. 2016. A Review of Cyanogenic Glycosides in Edible Plants. DOI: $10.5772 / 64886$

Bolarinwa, I.F., Olaniyan, S.A., Olatunde, S.J., Ayandokun, F.T. and Olaifa, I.A. 2016. Effect of processing on amygdalin and cyanide contents of some Nigerian Foods. J. Chem. Pharm. Res., 8(2): 106-113.

Bolarinwa, I.F., Orfila, C. and Morgan, M.R.A. 2014. Amygdalin content of seeds kernels and food products commerciallyavailable in the UK. Food Chem., 152: 1333-139.

Borade, V.P., Kadam, S.S. and Salunke, D.K. 1984. Changes in phytate phosphorus and minerals during germination and cooking of horse gram and moth bean. Qual. Plant Foods Hum. Nutr., 34: 151.

Bressani, R. 1993. Amaranth. In: Encyclopaedia of food science, food technology and nutrition. Eds. Macrae R, Rabinson RK, Sadler, MJ. London. Academic Press, pp. 135-140.

Brogren, M. and Savage, G.P. 2003. Bioavailability of soluble oxalate from spinach eaten with and without milk products. Asia Pacific J. Clin. Nutr., 12(2): 219-224.

Chattopadhyay, A., Saha, B., Pal, S., Bhattacharya, A. and Sen, H. 2010. Quantitative and qualitative aspects of elephant foot yam. International Journal of Vegetable Science, 16: 73-84. 
Combs, G. E., Conness, R.G., Berry, T.H. and Wallace, H.D. 1967. Effect of raw and heated soybeans on gain, nutrient digestibility, plasma amino acids and other blood constituents of growing swine. J. Anim. Sci. 26: 1067-1071.

Conn, E.E. 1979. Cyanide and cyanogenic glycosides. In: Hcrbi vores: Their interaction with secondary plant metabolites. Rosenthal, G.A. Janzen, D.H. (eds.) A.P., New York pp. 387412.

Conn, E.E. 1980. Cyanogenic compounds. Ann. Rev. Plant Physiol., 31: 433-451.

Connor, H.E. 1977. The poisonous plants in New Zealand: Wallington, New Zealand Government Printer, pp. 134.

Ebrahimi-Mahmoudabad S.R. and Taghinejad-Roudbaneh M. 2011. Investigation of electron beam irradiation effects on anti-nutritional factors, chemical composition and digestion kinetics of whole cottonseed, soybean and canola seeds. Radiation Physics and Chemistry, 80(12): 1441-1447.

Fassett, D.W. 1973. Oxalates: In toxicants occurring naturally in Foods. Washington D.C. National Acad. Scie., pp. 346-362.

Fenwick, D.E. and Oakenfull, D.G. 1983. Saponin content of food plants and some prepared foods. J. Sci. Food Agric., 34: 186-191.

Ferreira, V.L.P., Yotsuyanagi, K. and Carvalho, C.R.L. 1995. Elimination of cyanogenic compounds from bamboo shoots Dendrocalamus giganteus Munro. Trop. Sci., 35: 342-346.

Fombad, R.B. and Bryant, M.J. 2004. An evaluation of the use of cottonseed cake in the diet of growing pigs. Tropical Animal Health and Production, 36(3): 295-305.

Frank, E.Z., Honow, R. and Hesse, A. 2001. Calcium and oxalate content of the leaves of Phaseolus vulgaris at different calcium supply in relation to calcium oxalate crystal formation. J. Plant Physiol., 158: 139-144.

Gatel, F. 1994. Protein quality of legume seeds for nonruminant animals: a literature review. Anim. Feed Sci. Technol., 45: 317-348.

Gemede, H.F. and Ratta, N. 2014. Antinutritional factors in plant foods: potential health benefits and adverse effects. Glob. Adv. Res. Food Sci. Technol., 3(4):103-17.

Gholami, A., De Geyter, N., Pollier, J., Goormachtig, S., and Goossens, A. 2014. Natural product biosynthesis in Medicago species. Natural Product Reports, 31: 356-380.

Hang, D.T., Vanhanen, L. and Savage, G. 2012. Effect of simple processing methods on oxalate content of taro petioles and leaves grown in central Viet Nam. Food Science and Technol., pp. 1-5.

Hegarty, M.P. 1978. Toxic Amino Acids of plant origin. In: Effect of poisonous plants on livestock. Keeler, R.F., Van Kampen, K.R. and James, L.F. (eds.) Academic Press New York, pp. 575-585.
Holloway, W.D., Argall, M.E., Jealous, W.T., Lee, J.A. and Bradbury, J.H. 1989. Organic acids and calcium oxalate in tropical root crops. J. Agic. Food Chem., 37: 337-341.

Igbadul, B.D., Amoye, J. and Twadue, I. 2014. Effect of fermentation on the proximate composition, antinutritional factors and functional properties of cocoyam (Colocasia esculenta) flour. Afr. J. Food Sci. Technol., 5(3): 67-74.

Johnson, I.T., Gee, J.M., Price, K., Curl, C. and Fenwick, G.R. 1986. Influence of saponin on gut permeability and active nutrient transport in vitro. J. Nutr., 116: 2270-2277.

Jones, R.J. and Hegarty, M.P. 1984. The effect of different proportion of Leucaena leucocephala in the diet of cattle on growth, feed intake, thyroid function and urinary excretion of 3-hydroxy-4 (1H)-pyridone. Australian Journal of Agriculture Research, 35: 317.

Jood, S., Chauan, B.M. and Kapoor, A.C. 1986. Saponin content of chickpea and black gram: varietal differences and effects of processing and cooking methods. J. Food Agric., 37: 11211124.

Kataria, A., Chauhan, B.M. and Gandhi, S. 1988. Effect of domestic processing and cooking on the antinutrients of black gram. Food Chem., 30: 149-156.

Keeler, R.W. 1984. Teratogens in plants. Journal of Animal Science, 58: 1029-1039.

Kemdirimi, O.C.C., Chukwu, O.A. and Anchinewhu, S.C. 1995. Effect of traditional processing of cassava on the cyanide content of gari and cassava flour. Plant Foods Hum. Nutr., 48: 335-339.

Kenar, J.A. 2006. Reaction chemistry of gossypol and its derivatives. Journal of the American Oil Chemists' Society, 83(4): 269-302.

Khalil, A.H. and El-Adawy, T.A. 1994. Isolation, identification and toxicity of saponin from different legumes. Food Chem., 50: 197-201.

Khokhar, S. and Chauhan, B.M. 1986. Antinutritional factors in moth bean: varietal differences and effects of methods of domestic processing and cooking. J. Food Sci., 51: 591-594.

King, T.P., Begbie, R. and Cadenhead, A. 1983. Nutritional toxicity of raw kidney beans in pigs. Immunocytochemical and cytopathological studies on the gut and the pancreas. J. Sci. Food Agric., 34: 1404-1412.

Liebman, M. and Okombo, J. 2009. Oxalate content of selected pasta products. Journal of Food Composition and Analysis, 22: 254-256.

Liener, I.E. 1994. Implications of antinutritional components in soybean foods. Crit. Rev. Food Sci. Nutr., 34: 31-67.

Lim, S.J. and Lee, K.J. 2011. A microbial fermentation of soybean and cottonseed meal increases antioxidant activity and gossypol detoxification in diets for Nile tilapia, Oreochromis niloticus. Journal of the World Aquaculture Society, 42(4): 494-503. 
Lis, H. and Sharon, N. 1998. Lectins: carbohydrate-specific proteins that mediate cellular recognition. Chem. Rev., 98: 637-674.

Lyimo, M., Mugula, J. and Elias, T. 1992. Nutritive composition of broth from selected bean varieties cooked for various periods. J. Sci. Food Agric., 58: 535-539.

Mali, J.M., Kute L.S., Jambhale N.D. and Kadam S.S. 1990. Effect of leaf processing on antinutrients in leucaena seeds. Indian J. Anim. Sci., 60: 385-388.

Milgate, J. and Roberts, D.C.K. 1995. The nutritional \& biological significance of saponins. Nutr. Res., 15: 12231249.

Mosha, T.C., Gaga, H.E., Pace, R.D., Laswai, H.S. and Mtebek. 1995. Effect of blanching on the content of antinutritional factors in selected vegetables. Plant Food Hum. Nutr., 47: 361-367.

Nahrstedt, A. 1996. Relationships between the defense systems of plants and insects. In: Romeo, S.B. (Ed.), Recent Advances in Phytochemistry. Plenum Press, New York, pp. 217-230.

Noftsger, S.M., Hopkins, B.A., Diaz, D.E., Brownie, C. and Whitlow, L.W. 2000. Effect of whole and expanded-expelled cottonseed on milk yield and blood gossypol. Journal of Dairy Science, 83(11): 2539-2547.

Noonan, S.C. and Savage, G.P. 1999. Oxalate content of foods and its effect on humans. Asia Pacific J. Clin. Nutr., 8(1): 6474.

Oakenfull, D. and Sidhu, G.S. 1989. Saponins. In: Toxicants of Plant Origin, Vol. 11: Glycosides (Cheeke P, ed.), CRC Press, Boca Raton, FL, pp. 97-141.

Onabolu, A.O., Oluwole, O.S.A., Rosling, H. and Bokanga, M. 2002. Processing factors affecting the level of residual cyanohydrins in gari. J. Sci. Food Agric., 82: 966-969

Oscarsson, K.V. and Savage, G.P. 2007. Composition and availability of soluble and insoluble oxalates in raw and cooked taro (Colocasia esculenta var. Schott) leaves. Food Chemistry, 101: 559-562.

Petit, P.R., Sauvaire, Y.D., Hillaire-Buys, D.M., Leconte, O.M., Baissac, Y.G., Posin, G.R, et al. 1995. Steroid saponins from fenugreek seeds: extraction, purification, and pharmacological investigation on feeding behaviour and plasma cholesterol. Steroids, 60: 674-80.

Prasad, S. and Dhanya, M.S. 2011. Determination and detoxification of cyanide content in sorghum for ethanol production using Saccharomyces cerevisiae strain. J. Metabol. Syst. Biol., 2(1): 10-14.

Price, K.R., Johnson, I.T. and Fenwick, G.R. 1987. The chemistry and biological significance of saponins in food and feeding stuffs. CRC Crit. Rev. Food. Sci. Nutr., 26: 27-135.
Quintana, P.J.E., de Peyster, A., Klatzke, S. and Park, H.J. 2000. Gossypol-induced DNA breaks in rat lymphocytes are secondary to cytotoxicity. Toxicology Letters, 117(1-2): 85-94.

Rafińska, K., Pomastowski, P., Wrona, O., Górecki, R. and Buszewski, B. 2017. Medicago sativa as a source of secondary metabolites for agriculture and pharmaceutical industry. Phytochemistry Letters, 20: 520-539.

Ratanapo, S., Ngamjunyaporn, W. and Chulavatnatol, M. 1998. Sialic acid binding lectins from leaf of mulberry (Morus alba). Plant Sci., 139: 141-148.

Rogers G. M., Poore M. H. and Paschal J. C. 2002. Feeding cotton products to cattle. Veterinary Clinics of North America: Food Animal Practice, 18(2): 267-294.

Samtiya, M., Aluko, R.E. and Dhewa, T. 2020. Plant food anti-nutritional factors and their reduction strategies: an overview. Food Prod Process and Nutr., 2(6).

Savage, G.P., Vanhanen, L., Mason, S.M. and Ross, A.B. 2000. Effect of Cooking on the Soluble and Insoluble Oxalate Content of Some New Zealand Foods. Journal Food Composition and Analysis, 13: 201-206.

Shajeela, P.S., Mohan, V.R., Jesudas, L.L. and Tresina, S.P. 2011. Nutritional and Antinutritional Evaluation of Wild Yam (Dioscorea Spp.) [Evaluación Del Valor Nutricional Y Factores Antinutricionales De Dioscorea Spp. Silvestre]. Tropical and Subtropical Agroecosystems, 14: 723-730.

Sharma, A. and Sehgal, S. 1992. Effect of processing and cooking on the antinutritional factors of faba bean (Vicia faba). Food Chem., 43: 383-385.

Shawrang P., Mansouri M.H., Sadeghi A.A. and Ziaie F. 2011. Evaluation and comparison of gamma- and electron beam irradiation effects on total and free gossypol of cottonseed meal. Radiation Physics and Chemistry, 80(6): 761-762.

Sijun, D., Pawlak, A., Poźniak B. et al. 2012. Effects of gossypol acetic acid on cellular and humoral immune response in non-immunized and SRBC-immunized mice. CentralEuropean Journal of Immunology, 37(1): 11-19.

Singh, A.B., Awasthi, C.P. and Singh, N. 1999. Biochemical composition and nutritive value of promising collections of elephant foot yam (Amorphophallus companulatus Roxb.). Veg. Sci., 26(2): 186-187.

Siritunga, D. and Sayre, R.T. 2003. Generation of cyanogenfree transgenic cassava. Planta, 217: 367-373.

Sirohi, S.K., Pandey, N., Goel, N., Singh, B., Mohini, M., Pandey, P. and Chaudhry, P.P. 2009. Microbial Activity and Ruminal Methanogenesis as Affected by Plant Secondary Metabolites in Different Plant Extracts. International Journal of Civil and Environmental Engineering, 1(1): 52-58.

Smith, D.L. 1982. Calcium oxalate and carbonate deposits in plant cells. In: Anghileri, L.J. and Tuffet, Anghileri, A.M. Ed. The role of calcium in Biol Systems, CRS Press: Boca Raton. Florida, pp. 253-262. 
Soetan, K.O. and Oyewole, O.E. 2009. The need for adequate processing to reduce the antinutritional factors in plants used as human foods and animal feeds: A review. African Journal of Food Science, 3(9): 223-232.

Soetan, K.O. and Oyewole, O.E. 2009. The need for adequate processing to reduce the anti-nutritional factors in plants used as human foods and animal feeds: a review. Afr. J. Food Sci., 3(9): 223-32.

Soto-Blanco, B. 2008. Gossipol e fatores antinutricionais da soja, In: Toxicologia Aplicada a MedicIna VeterIn aria, H.S. Spinosa, S.L. Gorniak, and J.P. Neto, Eds., Manole, Barueri, 'Brazil, pp. 531-545.

Sparg, S.G., Light, M.E. and van Staden, J. 2004. Biological activities and distribution of plant saponins. J. Ethnopharmacol, 94(2-3): 219-43.

Tuncel, G., Nout, M.J.R. and Brimer, L. 1995. The effects of grinding, soaking and cooking on the degradation of amygdalin of bitter apricot seeds. Food Chem., 53: 447-451.

Uematsu, Y., Hirata, K. and Saito, K. 2000. Spectrophotometric determination of saponin in Yucca extract used as food additive. J. AOAC Int., 83: 1451-4.
Van, Damme, E.J.M., Hao, Q., Charels, D., Barre, A., Rouge', P., Van Leuven, F. and Peumans, W.J., 2000. Characterization and molecular cloning of two different type 2 ribosomeinactivating proteins from the monocotyledonous plant Polygonatum multiflorum. Eur. J. Biochem., 267: 2746-2759.

Vetter, J., 2000. Plant cyanogenic glycosides. Toxicon., 38: 11-36.

Vidal, V.C., Frias, J., Estrella, I., Gorospe, M.J., Ruiz, R. and Bacon, J. 1994. Effect of Processing on Some Antinutritional Factors of Lentils. J. Agric. Food Chem., 42(10): 2291-2295.

Yalcin, S. and Basman, A. 2015. Effects of infrared treatment on urease, trypsin inhibitor and lipoxygenase activities of soybean samples. Food Chem., 169: 203-10.

Yildirim, M., Lim, C., Wan, P.J. and Klesius, P.H. 2003. Growth performance and immune response of channel catfish (Ictalurus puctatus) fed diets containing graded levels of gossypol-acetic acid. Aquaculture, 219(1-4): 751-768.

Zagrobelny, M., Bak, S. and Møller, B.L. 2008. Cyanogenesis in plants and arthropods. Phytochemistry, 69(7): 1457-68. 
